\title{
Construction Of Female Identity In Pakistani Television Commercials (November, 2015-April, 2016): A Semiotic Analysis
}

\author{
Moneeba Iftikhar \\ \& \\ Mehwish Islam \\ Department of Mass Communication \\ Lahore College for Women University
}

\begin{abstract}
This study explores how TV commercials in Pakistan construct female identity in the present era. Advertising becomes an essential part in moulding and shaping our behaviour, attitude, values towards lifestyle and advertisers use visual, semiotic and printed text aims to convey their specific messages. This work attempts to analyze how the belief system of "flawless" and "perfect" society is created and constructed in and through advertisements. This study employed semiotic analysis as a research method to examine Pakistani TVCs. With stratified sampling technique, ten TVCs selected that appeared during intervals breaks of famous TV serials, obtained from main three private Pakistani channels, on a week after week premise for a time of six months. TVCs were analyzed with reference to the representation of Pakistani women in selected time period. As sign frameworks are included in the construction of meaning and advertising utilizes these signs to transmit its message. The ideologically developed messages, TVCs not only depict the image of women but have additionally made that image into the affirmed part of the female identity in the society. The overall findings reveal that women identity thrive in TV commercials that repeatedly represent women as glamorized sex object, there by not reflecting the different and progressive roles of women. This study is an effort to examine the advertising practice in Pakistan that how it constructs and depicts Pakistani women. Most commercials reveal today's Pakistani women as an independent glamorous and liberal object. This study would be significant for communication experts as well as for the policy makers who can apply it as a basis for creating and executing advertisements in future.
\end{abstract}

Keywords: TV Commercials, Construction of Women Identity, Semiotic Analysis.

$$
\begin{aligned}
& \text { تلخيص }
\end{aligned}
$$

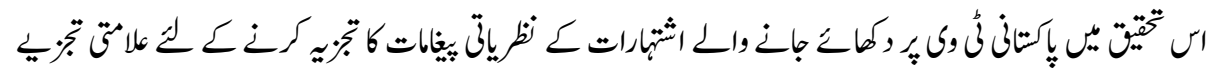

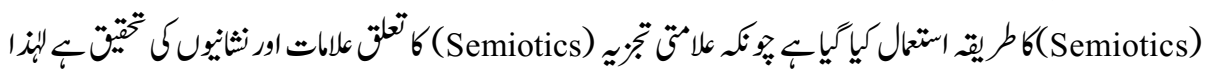

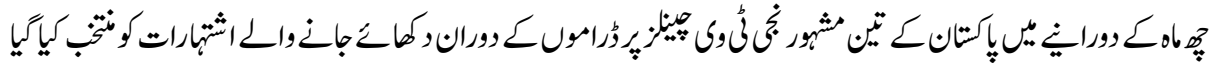

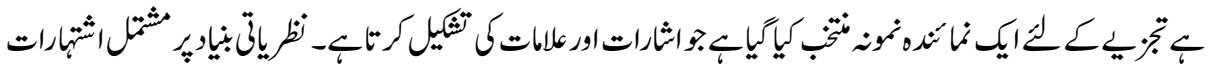




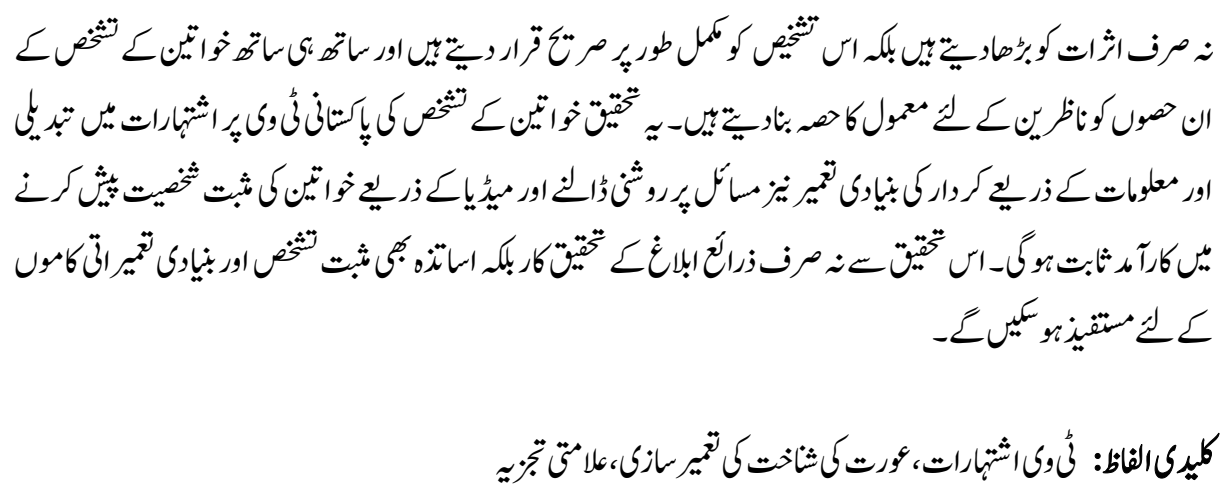

\section{Introduction}

Advertising is believed to become an essential part in shaping and developing our natures, qualities and thoughts towards way of life, decisions, and the choice between the morals and the immoral. Advertisers use visual, semiotic and printed text aims to convey their specific messages This concentrates and also looks at how the belief system of "flawless" and "perfect" society is created and constructed in and through commercials. For this reason, ten commercials have been chosen to investigate the distinctive roles performed by women. The commercials have been chosen from three popular Pakistani channels, HUM TV, ARY DIGITAL, GEO TV broadcasted in Pakistan under PEMRA.

The Ideology system is created by the signs that are contained in the commercial and its message. The ideology semiotic relationship is constructed as belief system makes use of signs to communicate its message (Bezuidenhout, 1998).

Advertising is very prominent amongst the most important and persuasive product of Television. In fact, the common adult spends through one and a half year of his or her life sitting in front of the TV watching commercials (Patel, 2012). The sum of time we spend watching commercials, it makes sense that it will have some sort of impact on the individuals who watch (Inghem, 1995) TV advertisements have caught the thoughts of consumers and makers for it is best than whatever other type of prior ad procedures accordingly used by majority producers or services providers.

Society is becoming complex everyday witness by us and we live and examine it daily (Andrew \& Sedgwick; 2008:82). Each political region has its own social patterns and demonstrated through their language, dress, the way individuals keep and present themselves. Each of these qualities merge to make identity for its people. Wearing this character individuals can be recognized anyplace on the world. Wearing a shalwaar, qameez and dupatah (head wear) a female can be perceived as Pakistani woman in any corner of the world. 
The dominance of commercials in our lives and its ability to influence and shaping our beliefs give it power over our society and the manipulation of our basic thoughts. The current study will be helpful for the readers to understand the current depiction of women in advertisement. This study will explore how the advertisers and advertising agency construct a women identity. This study will also employ the portrayal of women in media either its representation as glamorous or in a traditional way in society.

The researcher is trying to explore in Pakistan that what is in the mind of advertisers and advertising agency in a way to communicate a message and which identity they create? This study will explore the various ways that female characters are depicted in a sample of commercials in order to find out whether depiction of female characters are exact and true demonstration. It is supposed that woman characters are symbolized stereotypically; this is the overall result of studies that have also appeared at how women characters are portraying in commercials.

This study will also focus on stereotypes related with females in TV commercials. It is obvious to presume that typecast exists and are a part of our daily routine lives. Individuals act as per these stereotypes since stereotypes are considered socially satisfactory. For instance, when individuals think about a commercial for a family unit cleaner, what click in mind, probably, is a woman. It is also likely that the photo in individuals' psyches coordinates nearly to what researchers have called the happy housewife. This is a stereotype that has been connected with the picture of women in most TV ads.

\section{Literature Review}

The Ideology system is created by the signs that are contained in the commercial and its message. The ideology semiotic relationship is constructed as belief system makes use of signs to communicate its message (Bezuidenhout, 1998).

Advertising is very prominent amongst the most important and persuasive product of Television. In advertising, the commercial is this channel and dialect is the code" (Schrøder and Vestergaard, 1985) (cited from Wejher, 2015:2).

In fact, the common adult spends through one and a half year of his or her life sitting in front of the TV watching commercials (Patel, 2012). The sum of time we spend watching commercials, it makes sense that it will have some sort of impact on the individuals who watches it regularly (Inghem, 1995). TV ads present such concepts that people already have some sort of idea and information about them and advertising agencies by playing with these existing ideas bring to birth a new concept that looks normal and natural to people and as a result people readily except it. 
Advertising is always present social demonstration that both reflects and forms our lives (Roy, 1998). Advertising doesn't simply transmit product information rather spreads social representative information that encourages the forming of social patterns inside the society.

As Bouzida (2004) characterized semiotic as "semiotics is interrelated to the investigation of signs that allowed the propagation of various points of view and made the way to other social phenomena that raised the analysis of signs through its denotative and connotative implications" (p.1001). "Semiotics provides the meaning of the content and information of methods, visual and better understanding about the ways in social processes" (Solik 2014:209).

As sign frameworks are included in the construction of meaning (Chandler, 2001) and advertising utilizes these signs to transmit its message (Bezuidenhout, 1998), the ideologically developed messages, in the TV commercials not only depicts the images of women but have additionally made such images into the affirmed part of the of the female identity usual to the viewers in the society (Roy, 1998).

Cortese (2007) alludes to the idea of provocateur while talking about the picture of charming ladies commonly including on printed advertisements. The writer contends that "provocateur is not human; rather, she is a frame or empty shell representing a female stature" (Cortese, 2007:59). At the end of the day, Cortese (2007) considers the pictures of ladies including in commercials to be far off from reality, and examines the negative effects of this circumstance to self-confidence of delegates of "normal" female populace.

McAllister and West (2013), tell the reasons of pictures of ladies being utilized more as often as possible than pictures of men in media ads to emotional qualities of ladies. In particular, as indicated by McAllister and West (2013) it is simpler to convey different emotional human states, for example, satisfaction, outrage, interest, and so on through female pictures than pictures of men. Though, McAllister and West (2013) don't clarify their statements by alluding to any important exact review.

As indicated by Ross and Byerly (2008) generally media ads have situated females as passive and meek. In the meantime, Ross and Byerly (2008) express this recommended role for ladies in media is being changed right now, however certain restrictions still exist. Cheng and Chang (2009) identify with the role of women in media promoting to sex plea. Also, Cheng and Chang (2009) contend that this circumstance is not liable to change for a not so distant and creators make an effort to clarify this perspective by alluding the essential human instinct.

Mogel (2010) deals with the issues of media typecasting related to woman. In particular, as per Mogel (2010) media typecast take the part of woman in media as intimate object 
with passive characters. Biermann (2011) talks about the similar issue and contends that the role of females in many parts of the world is stereotyped by the media as housewives with the principle attentiveness toward house cleaning.

Emmauella Plakoyiannaki (2008) states that research on female Typecasts in advertisements is mainly slight, and there, we absence indication on whether women stand portrayed in projative (conventional) footings on the internet or not. Kyra Lanis \& Katherine Covell state that the influence of advertisements has extended been recognized. Inquiries of socio cultural encouragements on sexual arrogances must be narrower principally to trainings of sexually distinctive media. In this revision they inspected the belongings on sexual outlooks of different pictures of women in ads. Manly and feminine white middle-class academe apprentice was visible to one of three sets of ads. In one situation women are illustrated as sex stuffs, in additional in broad-minded or role reserved characters and a third state embraced creation leaning ads comprising no human records. Sexual outlook was evaluated by four gages of "Burt's Sexual Attitude Survey" of 1980, a portion of approaches supposed to be rape supportive, and encouraging to sexual hostility alongside women. Earlier finalizing the study, subjects valued a sequence of ads on appeal and visual level. However the creation leaning advertisements were graded as extra alluring than those presenting female numbers, analyses indicated that males uncovered to the sex object ads pointedly more patient of rape supportive insolences, and females bear to the reformist female metaphors were minus complaint of such insolences that were padels.

Goddard (2002) says the word advertising originates from a Latin verb "advertere" which signifies "to move in the direction of"; publicizing writings and linguistic dependably do their best to get individuals' consideration and rotate their head to the ad. He clarifies that behind publicizing content there is a mind goal of promoting or a mean to enhance the status or picture of advertiser. Straub and Attner (2007: 310) states that advertising "is any non individual message paid for by an identifiable patron with the end goal of advancing items, administrations or thoughts".

Every day we are overflowed with advertising messages based on different gender roles, depiction of social classes that help to form our cultural and social learning. Advertising is the major agent of social reinforcement (Roy, 1998). According to Davidson (1992), the role of advertising is not just limited to selling us products and services, but also imparts ways for us to understand the world. 
This study is an effort to find out the way in which the TV advertising messages are being constructed by advertising practitioner with reference to female identity. On the basis of above reviewed literature, following hypotheses are formulated for the study.

$\mathbf{H}^{\mathbf{1}}$ : Pakistani TVCs depict Pakistani women as traditional women

$\mathbf{H}^{2}$ : Pakistani TVCs depict Pakistani women as glamorous women

\section{Research Methodology}

The method of semiotic analysis is to discover the patterns of advertising representations and compare them to the actual values and characteristics of women in Pakistan. As quantitative research do not provide an in-depth analysis about the covered ideologies and the social communication of the production procedures (Norenee, 1977). Semiotics analysis as qualitative method has been selected to examine the Pakistani TV advertisements.

The basic population selected with the help of Stratified sampling in which woman sub strata (classified) into two categories either she is presented as traditional or as a liberal women. Following the sampling technique, ten Pakistani ads have been selected from TV primetime from three famous private channels in Nov 2015- April 2016) from stratified sampling.

\section{Analysis of Advertisements \& Discussions}

The main purpose behind these analyses of commercials is to highlight the ideological perception at the back of its production. This study has focused on the semiotics (gestures, dressing, setting and places) and linguistic including features of commercials as to analyze how these sponsored ideologies becomes so influential and powerful? In these analysis shots are used as a unit in the narration of commercials.

\section{TVC 1: Sunsilk black shine}

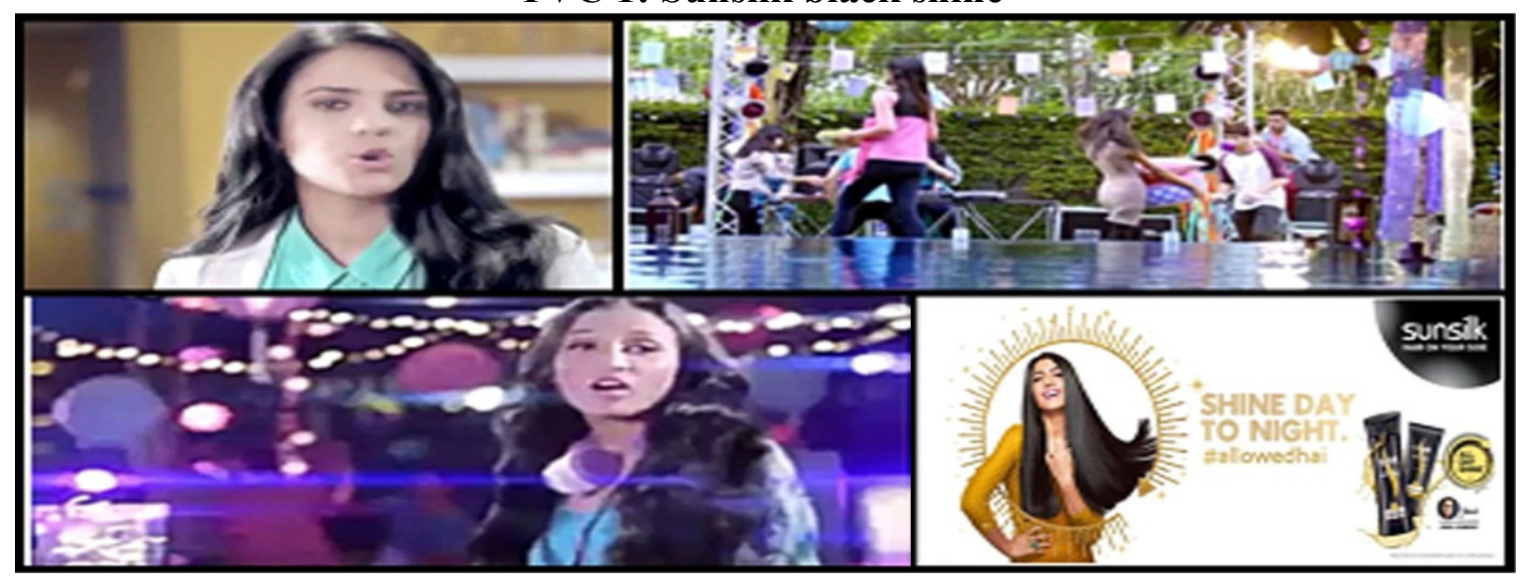




\begin{tabular}{|c|c|c|c|}
\hline $\begin{array}{l}\text { Sunsilk } \\
\text { Blackshine }\end{array}$ & & Signifier & Signified \\
\hline & $\begin{array}{l}\text { Screen } \\
\text { Elements }\end{array}$ & Long shiny hairs & Confidence/glamour \\
\hline & & Sign of "\#” & ongoing new trend \\
\hline & & Girl with a smile & Happy /confidence \\
\hline & & Shampoo Bottle & Product \\
\hline & & Sunsilk & Brand name \\
\hline & & Girl with open face & Strong / full confident \\
\hline & & Pool & Party/western culture \\
\hline & & Girl in jeans, shirt & Western culture \\
\hline & & Boys & Cross culture \\
\hline & & Girl with headphones & DJ \\
\hline & & $\begin{array}{l}\text { People sitting around the } \\
\text { pool }\end{array}$ & Party/fun / event organize \\
\hline & & Multi color Shawl & \\
\hline & & $\begin{array}{l}\text { Use of } 5 \text { natural oil } \\
\text { statement }\end{array}$ & $\begin{array}{l}\text { build a trust of consumer on } \\
\text { the product. }\end{array}$ \\
\hline & & Formal hair style & Outdoor/ working women \\
\hline & & $\begin{array}{l}\text { Oral slogan SHINE DAY } \\
\text { TO NIGHT \#allowedhai }\end{array}$ & Empowered girls \\
\hline & & $\begin{array}{l}\text { Written slogan Jab baal } \\
\text { hon saath Ban jaye har } \\
\text { baat }\end{array}$ & $\begin{array}{l}\text { Catchy key line/ focusing on } \\
\text { importance of hairs }\end{array}$ \\
\hline & & $\begin{array}{l}\text { Girl wearing dress with } \\
\text { white coat }\end{array}$ & Working women \\
\hline & & Sunsilk sachet & $\begin{array}{l}\text { introducing Sunsilk black } \\
\text { shine new packaging }\end{array}$ \\
\hline & & Formal dressing & Working women \\
\hline & & TVC is conversational & $\begin{array}{ll}\text { Characters } & \text { delivering } \\
\text { dialogues. } & \\
\end{array}$ \\
\hline & & Multi color Shawl & funky and bright mood \\
\hline & & Girls as a DJ & Working at night \\
\hline & & $\begin{array}{l}\begin{array}{l}\text { Price mentioning on } \\
\text { product }\end{array} \\
\end{array}$ & $\begin{array}{ll}\begin{array}{l}\text { Price information for } \\
\text { consumer }\end{array} & \end{array}$ \\
\hline & & Dialogues delivering style & They are educated girls \\
\hline & & Girl wearing sky blue shirt & $\begin{array}{l}\text { Soft /fresh selfless love/ } \\
\text { fidelity/freedom }\end{array}$ \\
\hline & & Young girls & Youth, passionate \\
\hline
\end{tabular}




\begin{tabular}{|l|l|l|l|}
\hline & Background & & \\
\hline & & Office & Working women \\
\hline & & Music board & DJ/party \\
\hline & Extra use of light & Glamour \\
\hline & $\begin{array}{l}\text { Sky converting day to } \\
\text { night }\end{array}$ & Full freedom \\
\hline & Colors & & Calm / soft/freedom \\
\hline & Sky blue & Freshness, happiness, energy \\
\hline & Yellow & Purity, innocence \\
\hline & White & Creativity, wisdom, pride \\
\hline & Purple & Power, elegance \\
\hline & & Black & \\
\hline
\end{tabular}

According to this commercial by use of Sunsilk black shine shampoo which shows that if their hairs shine they get confidence and can work whole day this concept signified the liberty relation with the shine of hairs. This ad is women empowerment, encourage liberty.

In the first scene its day time and the girls are working outdoor and indoor that is allowed to women that she can work in daytime and then showing the sky converting day to night and women still working freshly give the meaning and signifies that women can also work freshly and confidently at night also. And shows their black hairs still shinning at night give the positive impact on product. One character is in sky blue shirt with multicolor shawl signifies the funky and bright mood as a DJ with long and shiny hairs describe that using Sunsilk black shine gives her confidence from day to night. On the other hand, other girl wearing also same color dress shirt with white court which reflect her character that she is a professional women.

In this commercial girls are in western dressing, signifies modernity and glamour. Formal hair style signifies the working women at outdoor. Representation of one of the girl who is DJ make an impact on young girls that she is working in day time and not going home and start working at night which means the girls are have full freedom and have no restrictions. It is evidenced that $\mathrm{H}^{2}$ (Pakistani TVCs depict Pakistani women as glamorous women) has been recognized after the semiotic analysis of the selected commercial. 
TVC 2: Analysis of "Dalda Cooking Oil"

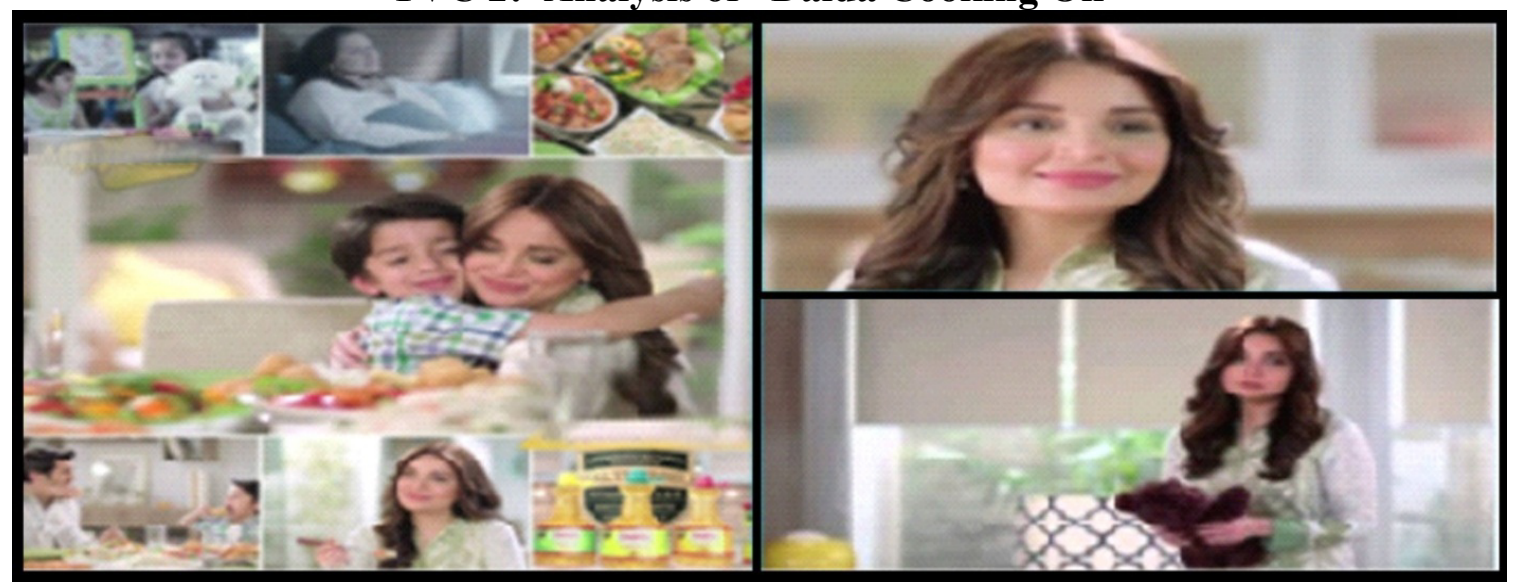

\begin{tabular}{|c|c|c|c|}
\hline $\begin{array}{l}\text { "Dalda } \\
\text { cooking } \\
\text { oil"' }\end{array}$ & $\begin{array}{l}\text { Screen } \\
\text { Elements }\end{array}$ & Signifier & Signified \\
\hline & & Different dishes on table & Party / formal dinner \\
\hline & & Girl with a deep smile & $\begin{array}{l}\text { Thinking about her loved } \\
\text { one might be her baby }\end{array}$ \\
\hline & & Oil Bottle & Product \\
\hline & & Dalda & Brand name \\
\hline & & Girl with tensed eyes & $\begin{array}{l}\text { Tension/ thinking about her } \\
\text { family }\end{array}$ \\
\hline & & Girl without duppatta & $\begin{array}{l}\text { Cross culture/western } \\
\text { culture }\end{array}$ \\
\hline & & $\begin{array}{l}\text { A woman lying on bed } \\
\text { thinking something }\end{array}$ & $\begin{array}{l}\text { Planning something/ } \\
\text { thinking about past or future }\end{array}$ \\
\hline & & Girl is hugging the kid & $\begin{array}{l}\text { Representing a motherly } \\
\text { nature/love }\end{array}$ \\
\hline & & Girl with spoon & Eating food \\
\hline & & A teddy bear in girl hand & She is a mother/ her kid toy \\
\hline & & $\begin{array}{l}\text { A man sharing food with } \\
\text { boy }\end{array}$ & Father son relation \\
\hline & & Two kids with teddy bear & They are playing \\
\hline & & Formal hair style & $\begin{array}{l}\text { Going to a party /attending a } \\
\text { formal dinner }\end{array}$ \\
\hline & & $\begin{array}{l}\text { Oral slogan" jahan mamta } \\
\text { wahan dalda" }\end{array}$ & $\begin{array}{l}\text { Emotional/ motherly/ } \\
\text { compare with mother care }\end{array}$ \\
\hline
\end{tabular}



A Semiotic Analysis

\begin{tabular}{|l|l|l|l|}
\hline & $\begin{array}{l}\text { Deep smile on girl face } \\
\text { while eating food }\end{array}$ & Good/sweet memories \\
\hline & & Girl wearing white dress & House wife/ innocence \\
\hline & Dalda steel box & Packaging in steel box also \\
\hline & Toys on table & Kids house \\
\hline & $\begin{array}{l}\text { Different packing of } \\
\text { bottles }\end{array}$ & $\begin{array}{l}\text { Variety of flavors in } \\
\text { product }\end{array}$ \\
\hline & Text vitamin A, D, E & $\begin{array}{l}\text { Vitamins/ healthy } \\
\text { ingredients }\end{array}$ \\
\hline & & Pink color lipstick & Soft/sweet \\
\hline & Background & House & Luxury / peace/ daily life \\
\hline & & Defocus background & Emphasis on characters \\
\hline & Colors & & Calm / soft/freedom \\
\hline & & Sky blue & Purity, innocence \\
\hline & & White & Renewal, nature, and energy \\
\hline & & Green & \\
\hline
\end{tabular}

This commercial is about Dalda Cooking oil. The commercial begins by showing the mother who is dressed in a 1 o $\mathrm{ng}$ shirt and trouser (shalwar) with a dialogue "Zindagi ma adjust to krna e parta ha", and wandering in her childhood memories where she performed different roles as a sister, daughter and in present as a mother and wife and justifying the dialogue adjust to "krna e parta ha".

This commercial depicts that the main role of a traditional woman is to serve family, as a sister is ready to share her things, secondly being a daughter she caters for the needs of others specially her mother and tries to comfort her in every possible way, thirdly as a wife where her main aim is to satisfy and fulfill the needs of her husband whether she is tired or unwell, lastly and mainly as a mother in this phase she completely forgets about herself and tend to ease her children at her extremes. The signs in the commercial are: teddy bear, lunch box and cushion. It all signifies that the Pakistani women's life revolves around her family. She selects the best and work tirelessly for the healthy life of her child. She is therefore keeping the womanly supreme of domesticity as she is positioned within the sphere of the home, specifically the kitchen, and it is her responsibility to cook for the family. She wears green dress which represents purity and peace but it is also scrutinized that she wears traditional "shalwar kameez" but without "dupatta" and this gesture shows her modernity blending with traditions. It is evident from above analysis that $\mathrm{H}^{1}$ has been acknowledged after the semiotic analysis of the selected commercial but the traditional dress with modern look also supports $\mathrm{H}^{2}$ to some extent. 
TVC 3: Analysis of "Galaxy J1 Ace"

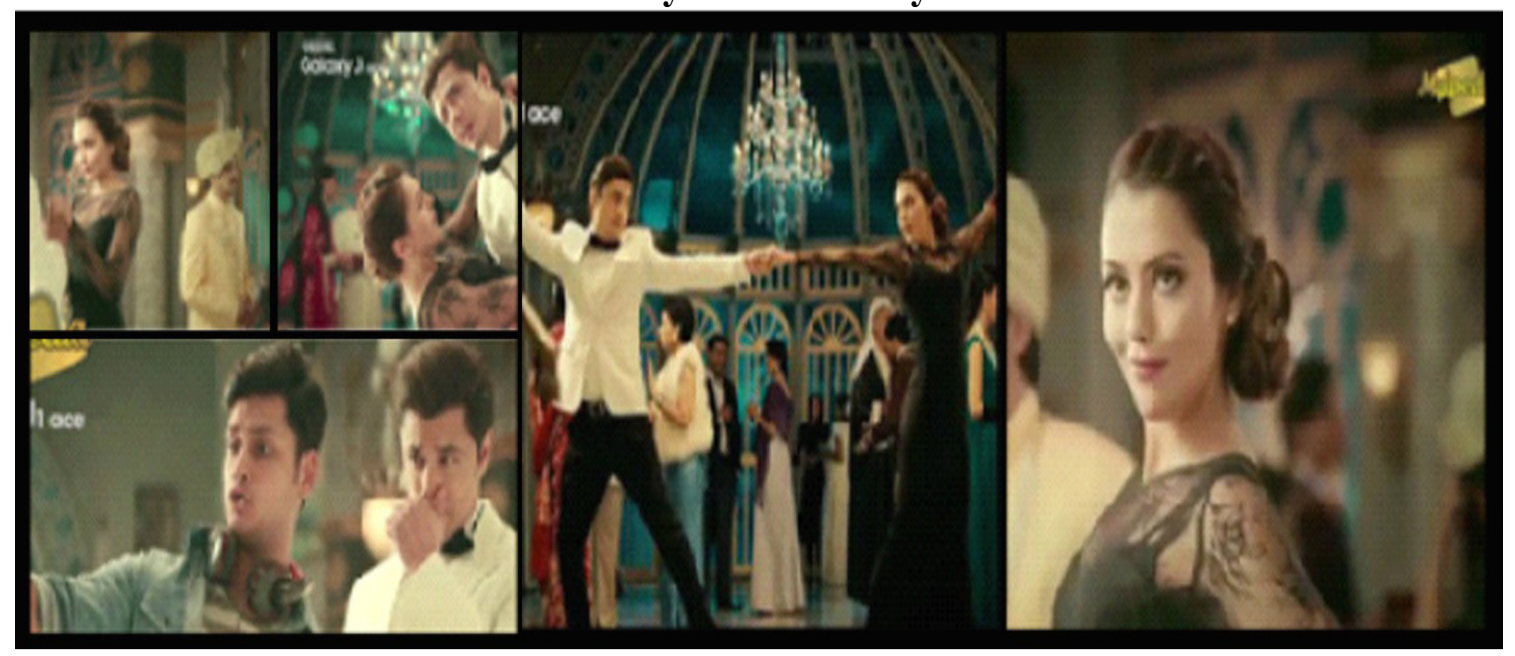

\begin{tabular}{|l|l|l|l|}
\hline Galaxy J1 Ace & Signifier & Signified \\
\hline & Screen Elements & Mobile in Hand & $\begin{array}{l}\text { Advert is about the } \\
\text { mobile/ Social /addict to } \\
\text { technology }\end{array}$ \\
\hline & & $\begin{array}{l}\text { Girl in black net } \\
\text { maxi }\end{array}$ & $\begin{array}{l}\text { Glamour/ fashion/ cross } \\
\text { socio culture }\end{array}$ \\
\hline & Girl with up chin & $\begin{array}{l}\text { Attitude / stance/ } \\
\text { Confidence }\end{array}$ \\
\hline & & Boy in dress & Gentleman \\
\hline & Boy and girl dancing & Cross culture \\
\hline & People enjoying & Party / function/ festive \\
\hline & $\begin{array}{l}\text { Brown hair with a } \\
\text { bun }\end{array}$ & Royal party appearance \\
\hline & Panorama & $\begin{array}{l}\text { Feature in Samsung } \\
\text { mobile }\end{array}$ \\
\hline & & $\begin{array}{l}\text { Girl in the hands of } \\
\text { boys }\end{array}$ & Cross culture \\
\hline & Ali zafar & $\begin{array}{l}\text { Boy dancing with } \\
\text { mobile }\end{array}$ & $\begin{array}{l}\text { He preferred mobile/ love } \\
\text { his mobile }\end{array}$ \\
\hline & People are dancing & Cross culture \\
\hline & Click her moment & Tagline of mobile advert \\
\hline & Boy pointing \\
towards mobile & $\begin{array}{l}\text { Referred to the other } \\
\text { people / best option }\end{array}$ \\
\hline & & & \\
\hline & & &
\end{tabular}


92 Construction of Female Identity in Pakistani Television Commercials (November, 2015-April, 2016):

A Semiotic Analysis

\begin{tabular}{|l|l|l|l|}
\hline & Boy dropped girl & $\begin{array}{l}\text { Mistreated girl over a } \\
\text { phone }\end{array}$ \\
\hline & & $\begin{array}{l}\text { People serve the } \\
\text { juice }\end{array}$ & Servants \\
\hline & Features of mobile & $\begin{array}{l}\text { Mobile function } \\
\text { information }\end{array}$ \\
\hline & Background & Palace & Glossy spot \\
\hline & & cameras & $\begin{array}{l}\text { Production/ something } \\
\text { capturing }\end{array}$ \\
\hline & & Crew & Production team \\
\hline & & Price mentioned & $\begin{array}{l}\text { Price information for } \\
\text { consumer }\end{array}$ \\
\hline & & Click her moment & Mobile tagline \\
\hline & Colors & Metallic color & Lustrous; sparkling \\
\hline & & Black color & $\begin{array}{l}\text { luxurious attitude, } \\
\text { sophistication, power, }\end{array}$ \\
\hline & &
\end{tabular}

The male (Ali Zafar a renowed celebrity) and ravishing female (Azlan Shah) became the new appearance of Samsung to introduce its Galaxy J series in Pakistan. The commercial is really appealing with lively music and expressions. The male dance moves gives a romantic and enchanting effect to the video. Royal and metallic color scheme has been used in this advertisement for a deluxe ambience. The scenario of a royal party is portrayed. The black partially "see through" net night gown of the female along with western dancing moves with the dominant male signifies sex, glamour and a liberal but a recessive female. The way he treated his lady co-star in the Ad was so discourteous. He dropped her on the floor over a phone. The culture in the ad signifies to western lifestyle and glamour. In this commercial again the left hand source or the identity constructor creates the false notion of Pakistani women. It is evident that $\mathrm{H}^{2}$ has been accepted after the semiotic analysis of the selected TV commercial. 
TVC 4: Analysis of "Cake Rusk"

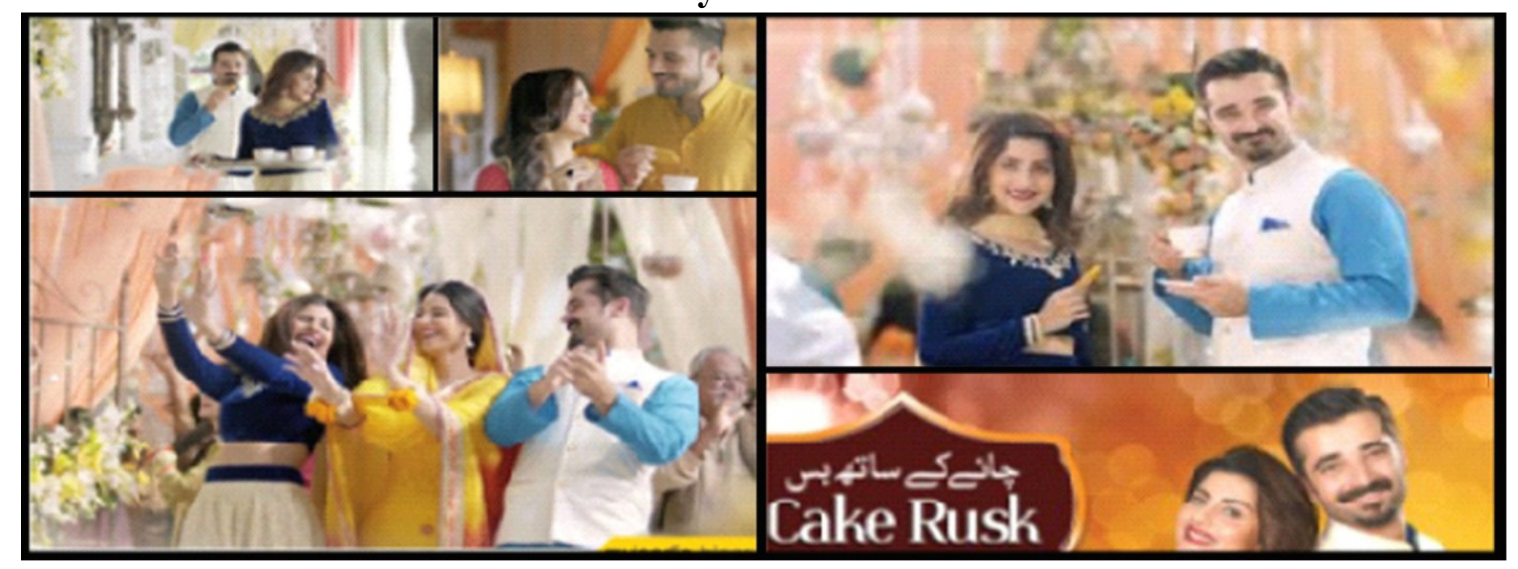

\begin{tabular}{|l|l|l|l|}
\hline Cake Rusk & & Signifier & Signified \\
\hline & $\begin{array}{l}\text { Screen } \\
\text { Elements }\end{array}$ & Cake rusk & Product \\
\hline & & Dance & Wedding/occasion \\
\hline & & Girl in yellow dress & Mayo bride/ Ubtan \\
\hline & & Airl in lahnga & Wedding function \\
\hline & & Girl dancing with boy & $\begin{array}{l}\text { Tea time/ Rusk combination } \\
\text { with tea }\end{array}$ \\
\hline & Boy grasps the girl hand & $\begin{array}{l}\text { Taking interest/sex appeal/ } \\
\text { cross culture }\end{array}$ \\
\hline & & Tea cups & Tea time \\
\hline & Makeover & Festive / wedding function \\
\hline & Boy staring the girl & Taking interest/ likeness \\
\hline & Girl wearing half blouse & Cross culture/nudity/obscenity \\
\hline & Jewellery & Fashion/function/stardom \\
\hline & $\begin{array}{l}\text { Girl and boy standing very } \\
\text { close to each other }\end{array}$ & Cross culture \\
\hline & Tray of tea cups & tea-time delicacy \\
\hline & & Cake rusk chaye k sath & $\begin{array}{l}\text { Tagline defining the } \\
\text { combination of rusk with tea }\end{array}$ \\
\hline & & Nude belly & Vulgarity/modernism \\
\hline & & Cookania & Product brand \\
\hline & & Fveryone seems busy & Wedding house \\
\hline & & $\begin{array}{l}\text { Man sharing rusk with } \\
\text { worker }\end{array}$ & $\begin{array}{l}\text { Positive vibes/ } \\
\text { kindness/modest }\end{array}$ \\
\hline & & & \\
\hline & & &
\end{tabular}


A Semiotic Analysis

\begin{tabular}{|l|l|l|l|}
\hline & Background & & \\
\hline & & Ayi ayi mazay ki rut ayi & Advertisement Track \\
\hline & & House Decorations & Wedding event \\
\hline & & Defocus & More emphasis on character \\
\hline & Colors & Blue & trust, loyalty/freedom \\
\hline & & Yellow & Freshness, happiness, energy \\
\hline & & White & Purity, innocence \\
\hline & & Brown & Genuineness \\
\hline & & Pink & $\begin{array}{l}\text { Love, friendship, affection, } \\
\text { harmony, inner peace, }\end{array}$ \\
\hline
\end{tabular}

This TV ad went with Cake Rusk is a refreshing treat with tea. Demonstrating the rich hues, arrangements, enthusiasm and music to make the glory, the male model (Hamza Ali Abbasi) and female model (Sohai Ali Abro) were considered as the facade of Cake Rusk message. The male in the ad with his love feelings and looks with the female (Sohai) having a vigorous personality was to show the pre-wedding excitement. In this commercial girl has shown in typical traditional dress with a short blouse which is not according to Pakistani culture or ideology. Formal hair style signifies that they are enjoying the wedding occasion.

In the middle of this ad the man is attracting towards girl, he is touching her hand and a sex appeal being showed in this commercial. Male partner is holding woman hand and tried to catch her and woman is trying to inspire him by her alluring feministic presence. That is something that re-presents the women identity or constructs women identity as a sex symbol with a blend of semi cultural and glamorous looks because a half blouse with nude belly can be related for sure with to the sex appeal and glamour for audience. It is evidenced that $\mathrm{H}^{2}$ has been acknowledged after the semiotic analysis of the selected commercial.

\section{TVC 5: Hilal Freshup Elaichi}

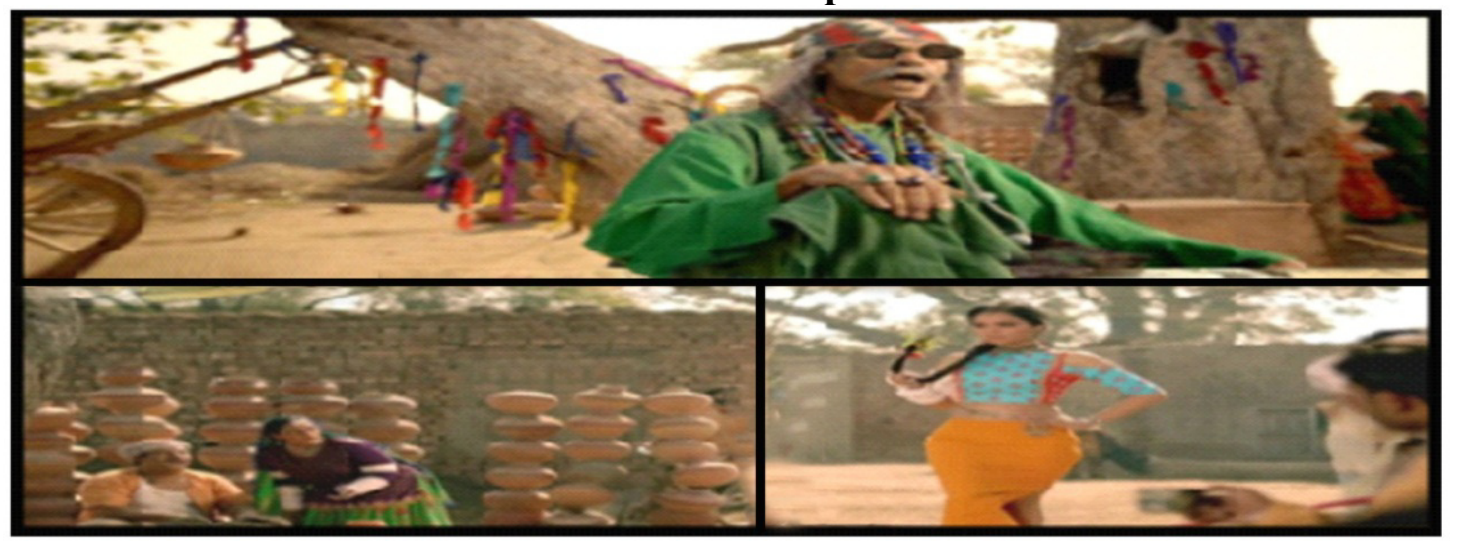




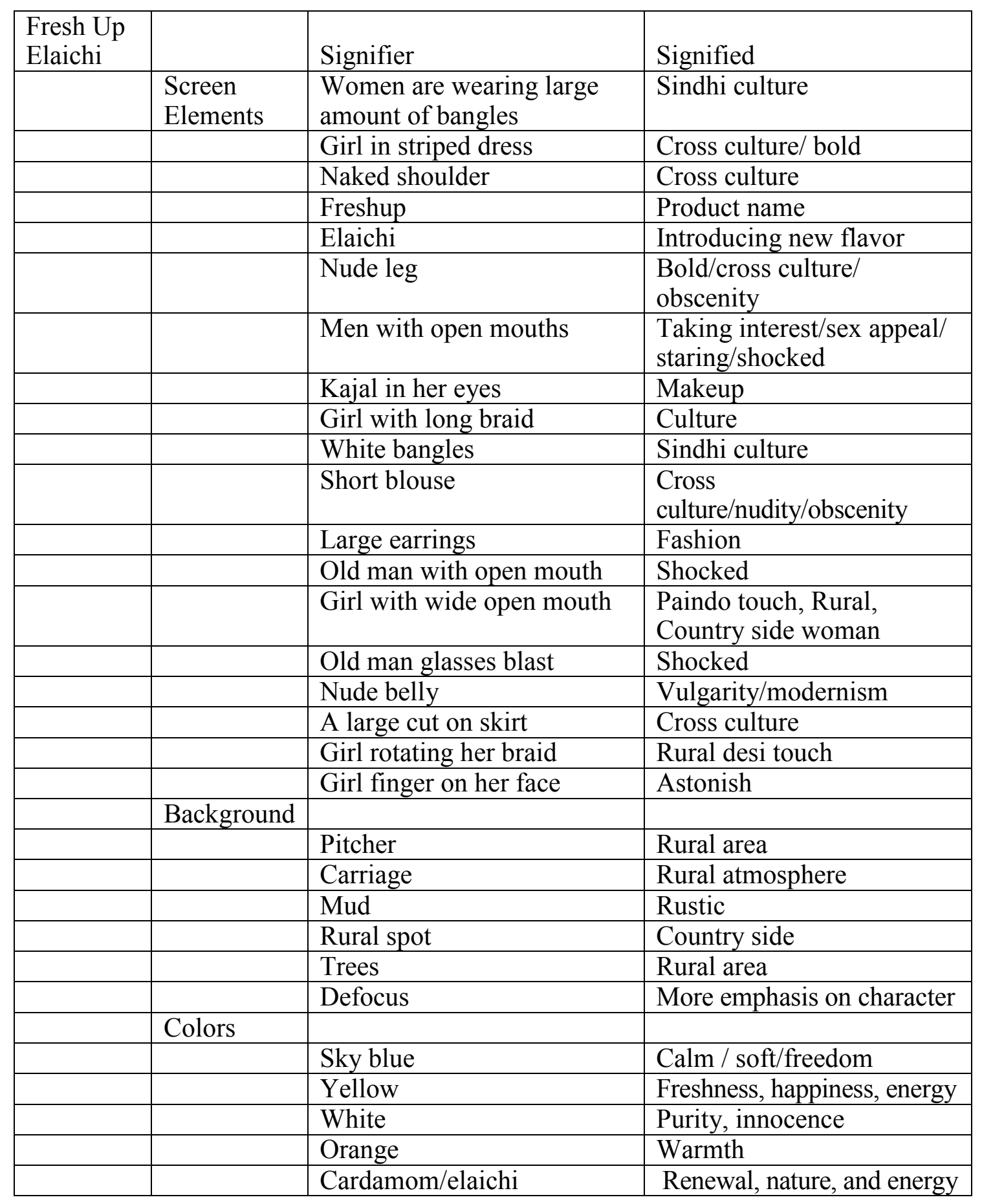

Hilal Freshup new Elaichi TVC 2015 "Desi Ko Laga New Touch Elaichi Ho Gai Freshup" a new concept of Hilal freshup Elaichi. Concept based on transformation of a village girl into 
the hot and alluring girl, the village and turned out into a fusion beat. No doubt modernism and change makes its place very quickly. People take notice get attract and criticize.

A song played and the character "Raziaa" entered in the scene makes the whole atmosphere silent, the people leaving their work just staring at her as if they had nothing else to do, that signifies society take this changing as a piece of entertainment, temptation rather than beauty and a good change. The old man glasses blast out, the potter ruined the pot and the painter started painting man's face. These are highlighted moments of the commercial these moments signified that people taking her as sex symbol, seduction or sexually aroused with her new transformation.

Costume of model is very revealing that signifies that concept of ad is cross culture. The naked shoulder of girl and exposing belly is just a sign of pursuing glamour. The girl wears a deteriorated Sindhi traditional dress. Other characters are representing rural background but the environment of village is in contrast to the original village. Colors are bright and attractive. The background pitcher and horse carriage is also supporting the theme of the commercial. The overall focus of this ad was on liberal sexy girl which represents glamour in rural area. It is proved that $\mathrm{H}^{2}$ has been accepted after the semiotic analysis of the selected commercial.

TVC 6: Analysis of "Nan Khatai"

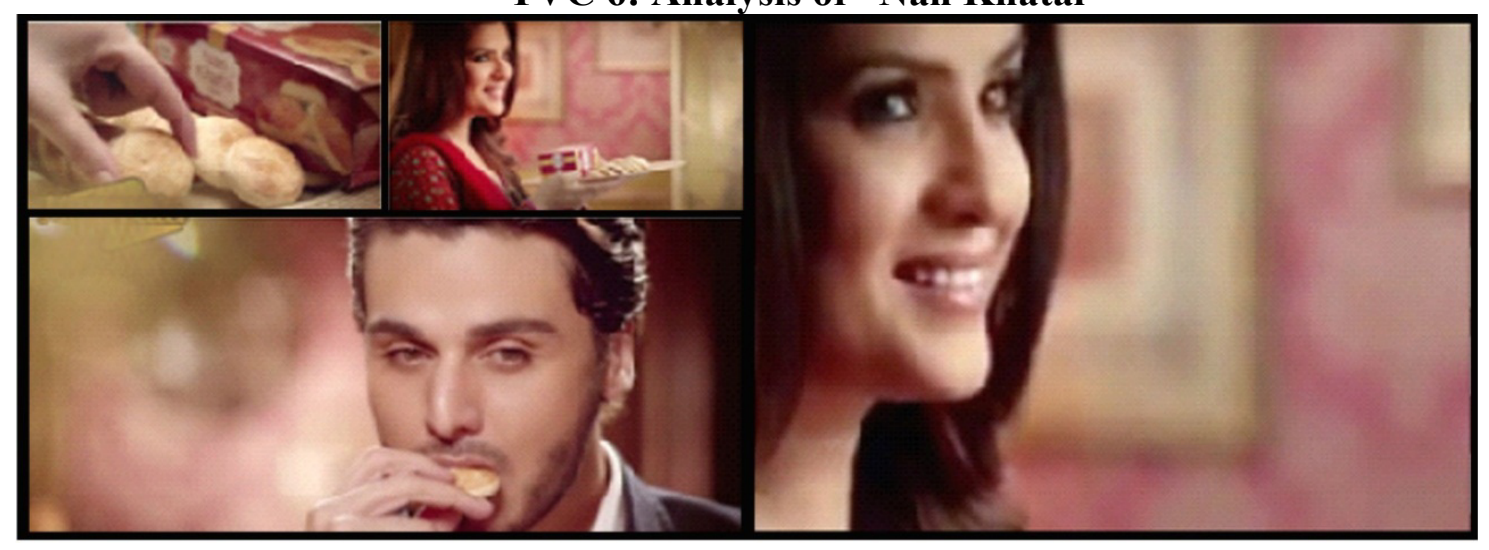

\begin{tabular}{|l|l|l|l|}
\hline $\begin{array}{l}\text { Peak Freans } \\
\text { Nan Khatai }\end{array}$ & Signifier & Signified \\
\hline & $\begin{array}{l}\text { Screen } \\
\text { Elements }\end{array}$ & Desi ghee & Product ingredient \\
\hline & & Clock & Waiting/ House decoration \\
\hline & & Tea set & Household items \\
\hline & & Couple smiling & Sharing happy moments \\
\hline & & Naan khatai & Product \\
\hline & & Peak freans & Brand \\
\hline & & Gift & Share love \\
\hline
\end{tabular}




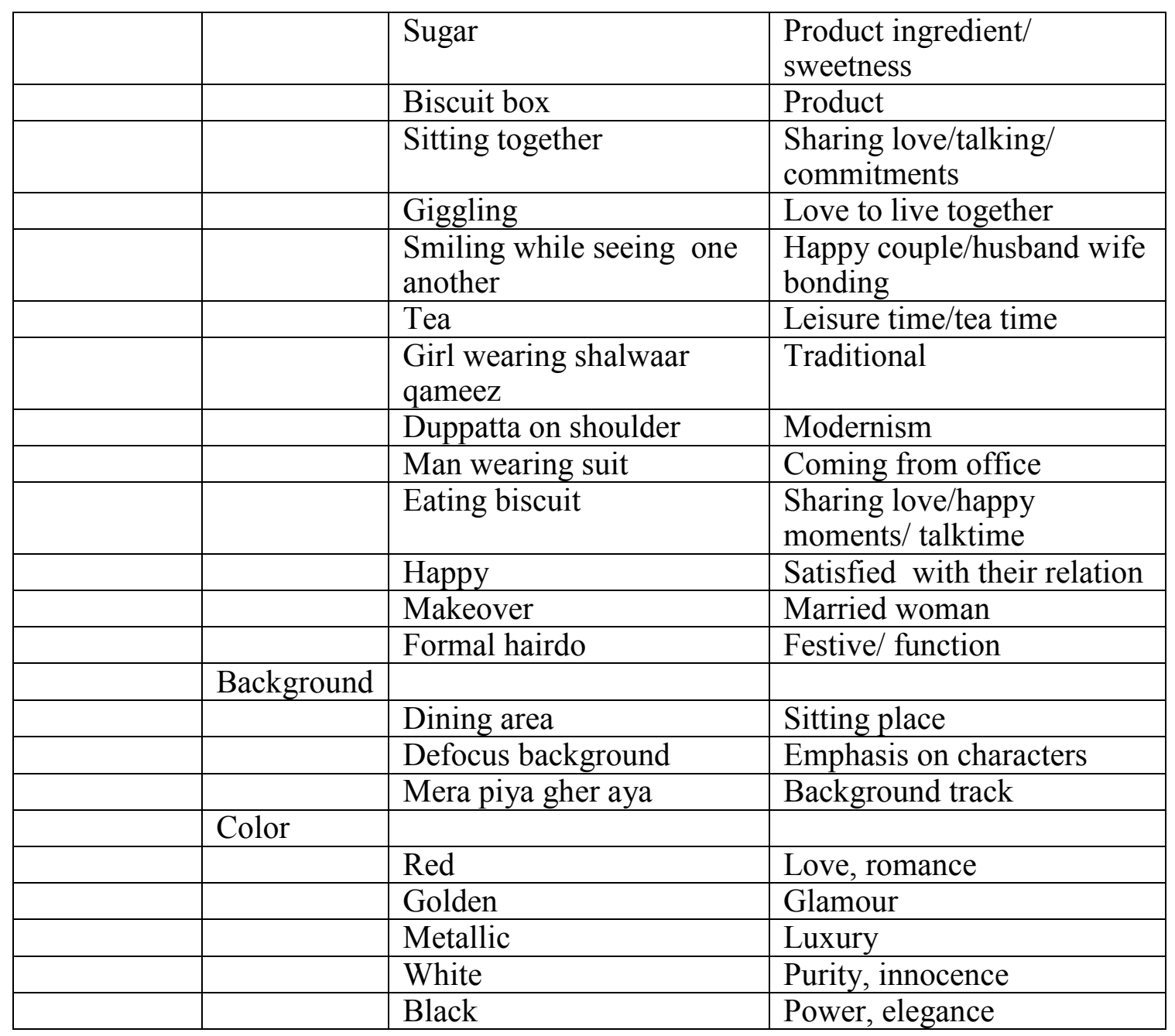

In the advertisement former film star Resham in red embrioded dress along with jewelry is walking down the corridor to her dining area where there is some tea in a beautiful tea set along with a box of "Naan Khatai" on the table. The red color of her dress represents love and happy married life. She looks desperately on the clock as she is waiting for her husband (Ahsan Khan). Her expressions signify traditional life style of Pakistani house wife. The female brings "NanKhatai" and set it in a tray with cups of Tea. Her husband eats it so deliciously which represents good taste. The expression of her husband (Ahsan khan) while eating "Nankhatai" is perfectly matched with the requirement.

A romantic ad has ends when her husband gives her a gift with a loveable smile and camera closes with the tagline with a voice over "peek freans "Nankhatai", "mazay ki sogat". The catchy track behind the commercial makes it more attractive like "mera piya gher ya" is a connotation of love $\mathrm{n}$ happy married life. Clock signifies in this commercial 
about wait that she looks desperately on the clock as she is waiting for her husband. Couple smiling signifies they are sharing happy moments and husband feeling happy and light with her wife. Gift signifies augment love of her husband towards her. Sitting together shows they are sharing love/talking or making commitment or they are enjoying each other company.

In this advertisement the female identity is constructed as traditional women with elegant traditional dressing, light jewelry and makeup. Orthodox ideology based theme of this commercial as it emphasized the domestically role of women as a housewife as she carried out the roles of a wife. The commercial likely to present a traditional image of the family as the woman carried out the duties of a wife. It is evidenced that $\mathrm{H}^{1}$ has been acknowledged after the semiotic analysis of the selected commercial.

TVC 7: Analysis of "Lux Jasmine"

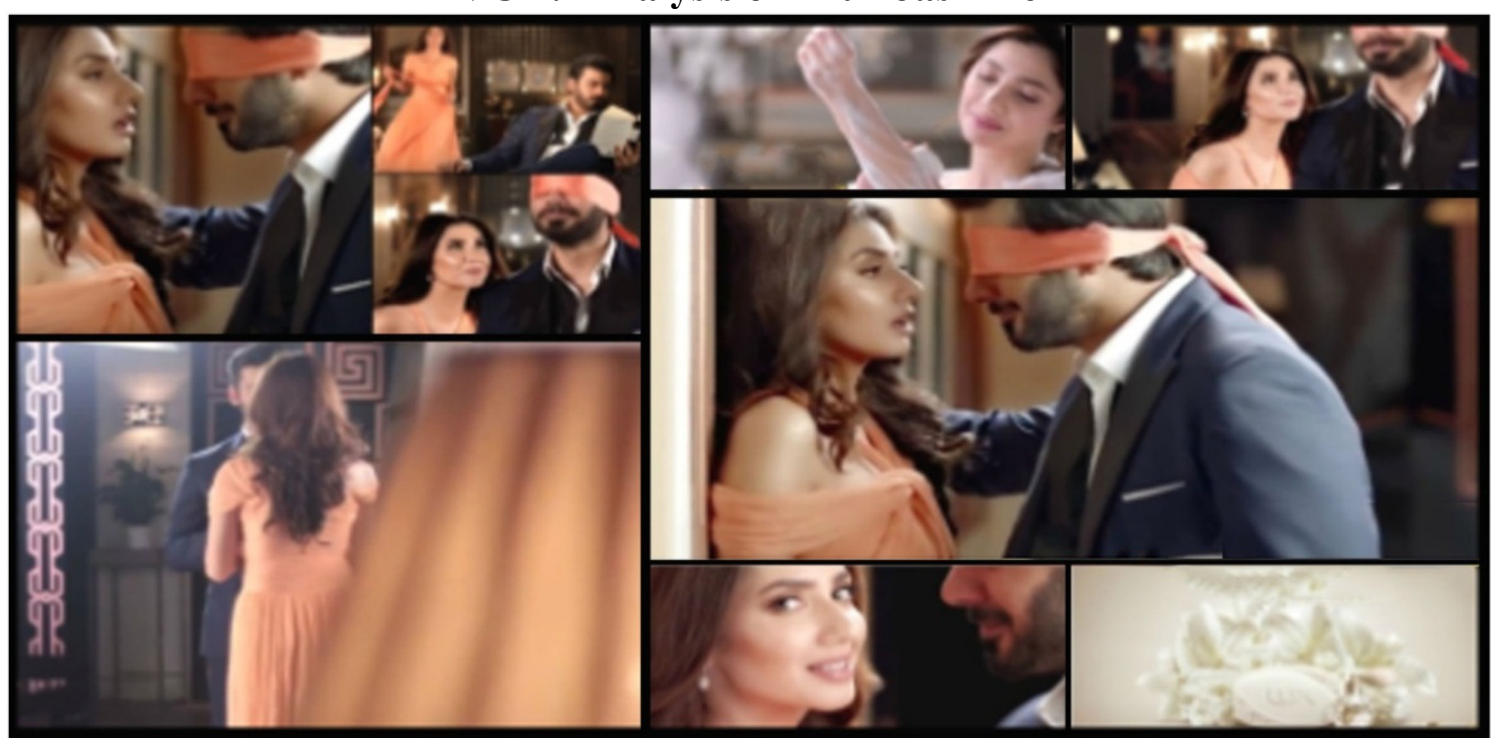

\begin{tabular}{|l|l|l|l|}
\hline "Lux" & Signifier & Signified \\
\hline & $\begin{array}{l}\text { Screen } \\
\text { Elements }\end{array}$ & Girl taking bath & $\begin{array}{l}\text { Sexuality/Cross } \\
\text { culture/unacceptable culture }\end{array}$ \\
\hline & & Half naked girl & Sex appeal/ exposing body \\
\hline & & Girl with a smile & Victory \\
\hline & & Soap & Product \\
\hline & & lux & Brand name \\
\hline & & Girl biting lips & $\begin{array}{l}\text { Attracting/intimating } \\
\text { opposite sex/seduction }\end{array}$ \\
\hline & & Girl in peach maxi & Cross culture/western \\
\hline
\end{tabular}




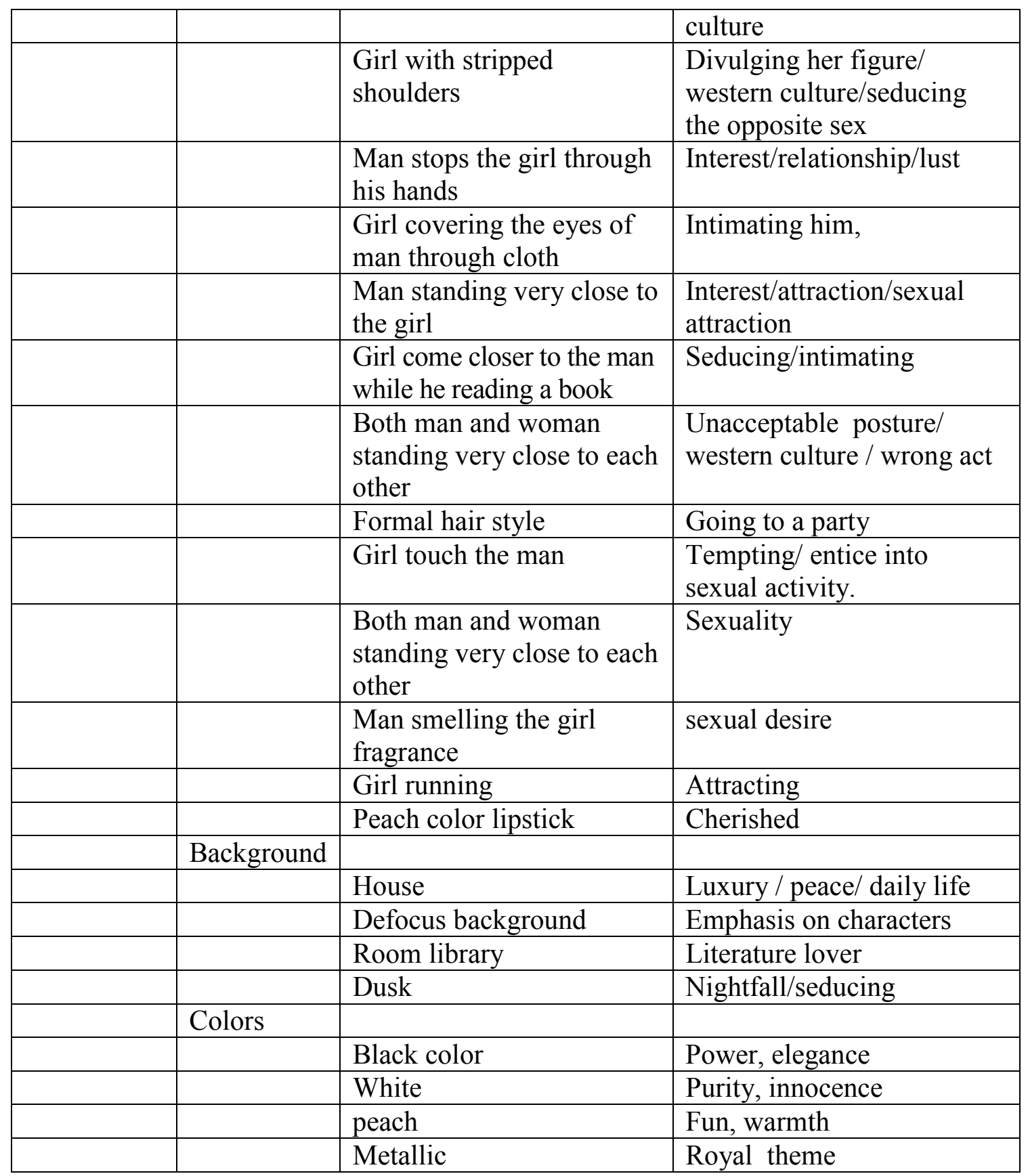

Lux project has linked a number of adjectives to interpret its sense of beauty like alluring; bold, happy, confident, flirty, glamorous, beautiful, irresistible, attention-grabbing etc. This commercial is portrayed in some modern and elite class location. Camera opens in a lavatory where an energetic lovely lady (Mahira Khan) in her twenties is demonstrated 
enjoying shower in the shower tub is by all accounts motivated by the scent of Lux soap. In next scene the same woman is exposed again with a young man (Fawad Khan) in a home library. Man feeling the presence of women by smelling the fragrance of her that she gets after bath with lux. Female ties a piece of cloth on his eyes and played hide and seek with him. Male partner is holding woman's hand and tried to catch her while woman is trying to inspire him by her alluring feministic presence.

Male (Fawad Khan) is wearing black formal outfit in contrast of the peach by the female spouse (Mahira Khan), showing his masculinity and self-confidence in approaching her. It signifies his affluent and successful life. Many expressions are caught in camera in this ad are note- worthy. Lady in the ad shows more expression than her male partner signifying that female is enjoying more sensational attacks by male and female also exploited much of her body language; her contact shows a kind of self-affirmation. At the end of the commercial both are sharing an eye contact that signifying promise of intimate relationship between them.

"Lux jasmine" the leading female (Mahira Khan) character depicts herself quite glamorous and sexual. The whole commercial deals with the sexual exposure of woman and create the complete impression of the commercial depicts women in glamorous and sexual way. As the analysis of semiotics there has been also proved that glamour has been also related to the colors, costumes, expressions, peach naked shoulder maxi all are signifies glamour. The whole commercial signifies the glamour and stardom. It is evidenced that $\mathrm{H}^{2}$ has been acknowledged after the semiotic analysis of the selected commercial.

TVC 8: Analysis of "Q Mobile Noir S2"

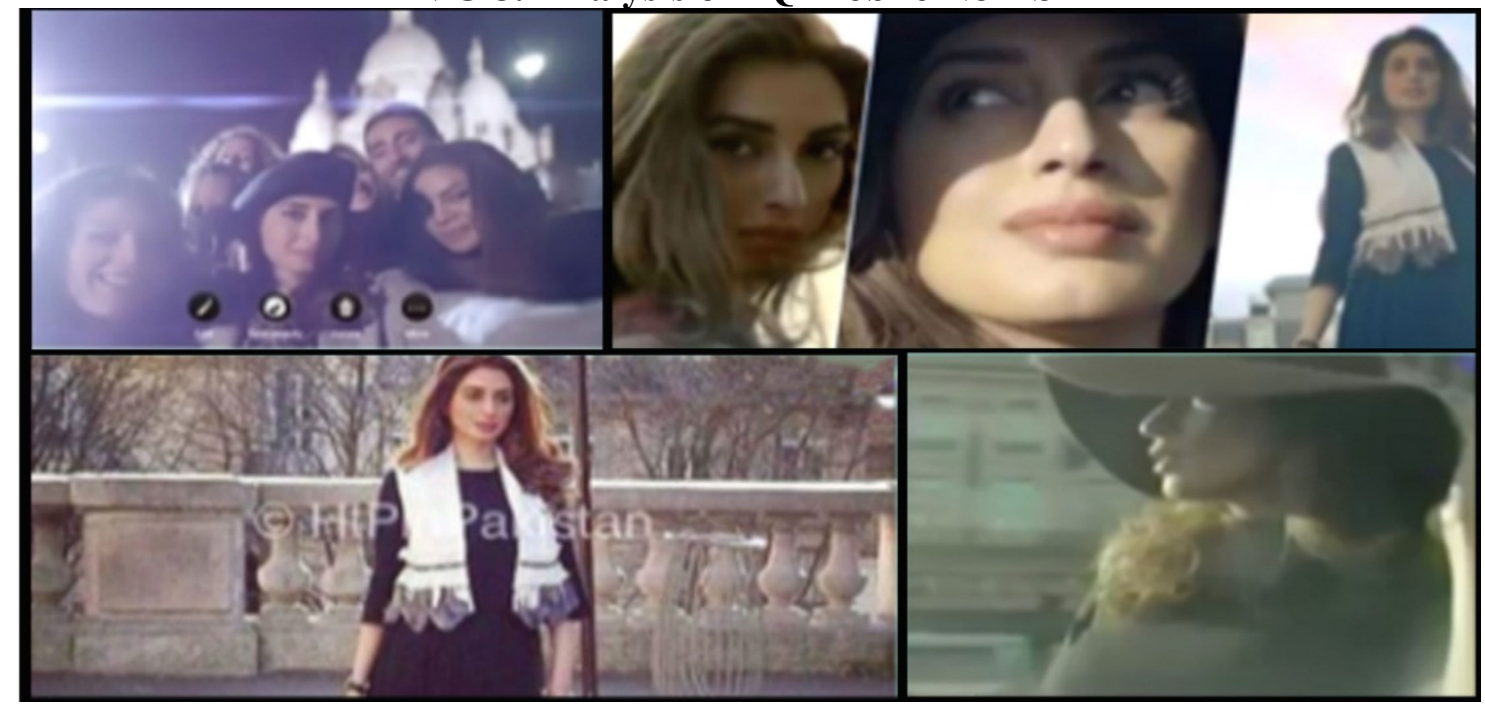




\begin{tabular}{|l|l|l|l|}
\hline $\begin{array}{l}\text { Qmobile } \\
\text { noir s2 }\end{array}$ & $\begin{array}{l}\text { Screen } \\
\text { Elements }\end{array}$ & Signifier & Signified \\
\hline & & Hat & \\
\hline & & Mobile in hand & Fashion/ Glamour \\
\hline & & Skirt & Social /addict to technology \\
\hline & & Overcoat & French dress \\
\hline & & Looking upward & Confidence \\
\hline & & Group of people & Might taking a selfie/picture \\
\hline & & Frizzy brown hair & Glamour \\
\hline & & large pupils & Attractive look \\
\hline & Background & & \\
\hline & & Paris opera house, & Paris Glossy spot \\
\hline & & Arc de Triomphe & Paris Glossy spot \\
\hline & & $\begin{array}{l}\text { English Text “Capture you } \\
\text { world" }\end{array}$ & French track \\
\hline & & Eiffel tower & Paris Glossy spot \\
\hline & Colors & & Foggy atmosphere \\
\hline & & Silver and grey & $\begin{array}{l}\text { luxurious attitude, } \\
\text { sophistication, power, }\end{array}$ \\
\hline & & Black color &
\end{tabular}

The story of the advertisement is a young female (featuring Iman Ali) has gone on a trip to Paris all alone and when someone goes on a trip he/she wants to capture all the places he/she travels .If your trip location is a beautiful place like Paris then you should have a phone like Q Mobile Noir S2. The advert is more like a glamorous act. The lady is scrolling fine-looking places wearing western dresses. To achieve a glamorize look the Face of the lady in this ad features large pupils because people are attracted towards eyes. There are more close ups to enhance the look of a glamorous liberal women. As a tourist in Paris, the young lady wears outfits according to the western culture and western ambience can be felt. The story of the advertisement features a girl alone on a foreign trip which is still considered a taboo among most of the population of Pakistan. Taking "selfies" with so many tourists and roaming all alone on the streets of Paris is a connotation of liberty and confidence. The Background score is originally a song in French language which means that this advertisement is supposed to be inspired by the western (French) music. Iman Ali stands among the most glamorous celebrities of Pakistan and is being presented as an independent liberal, glamorous woman in this TV commercial. Hence it is evinced that $\mathrm{H}^{2}$ has been accepted after the semiotic analysis of the selected commercial. 
102 Construction of Female Identity in Pakistani Television Commercials (November, 2015-April, 2016): A Semiotic Analysis

\section{TVC 9: Tarang Elaichi}

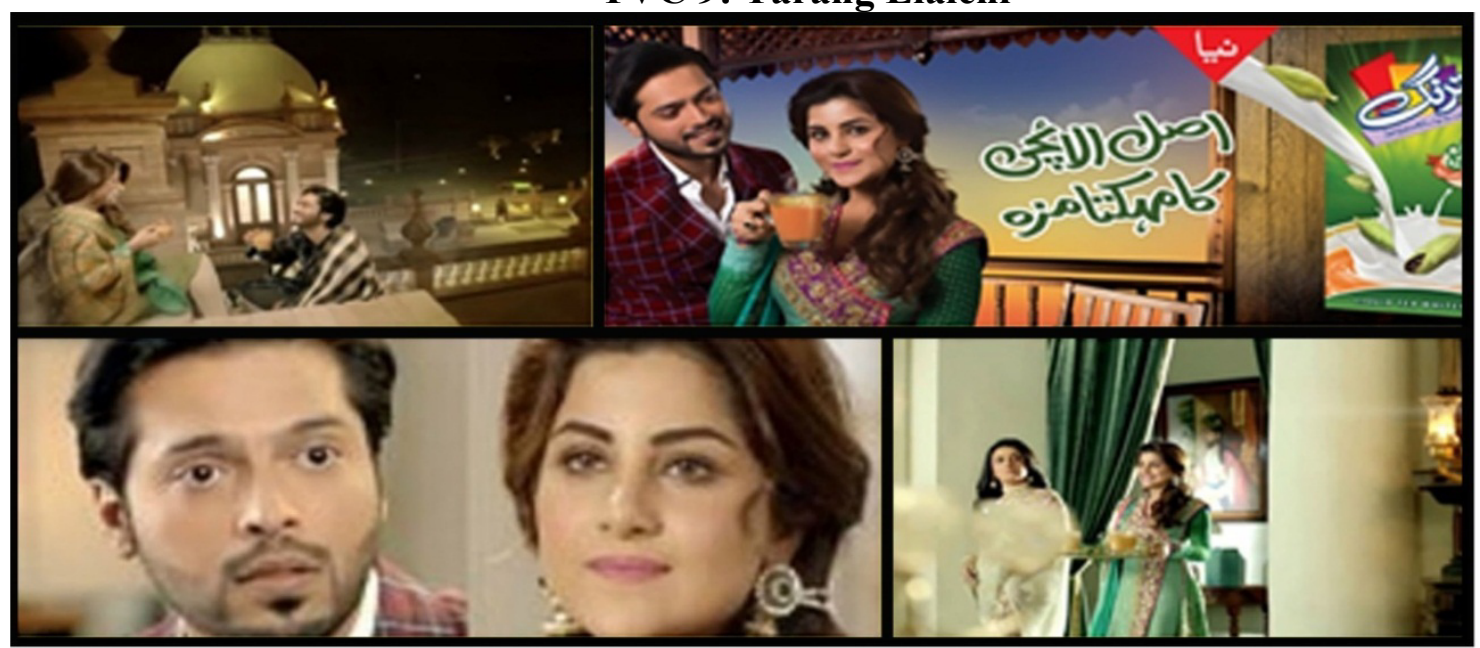

\begin{tabular}{|c|c|c|c|}
\hline $\begin{array}{l}\text { TARANG } \\
\text { ELAICHI }\end{array}$ & & Signifier & Signified \\
\hline & $\begin{array}{l}\text { Screen } \\
\text { Elements }\end{array}$ & & \\
\hline & & Jewellery & Fashion/ Glamour \\
\hline & & Cup in hand & Tea time/leisure time \\
\hline & & $\begin{array}{l}\text { Girl holding a tray of tea } \\
\text { cups }\end{array}$ & Get together/ guest arrival \\
\hline & & $\begin{array}{l}\text { Shawls covering the } \\
\text { characters }\end{array}$ & Winters \\
\hline & & Open eyes of man & Fear \\
\hline & & Girl with narrow eyes & Anger \\
\hline & & Man sitting below the girl & Female dominancy \\
\hline & & Milk Packet & Milk / product \\
\hline & & Cardamom & Introducing a new taste \\
\hline & & Women beside the girl & Mother/Mother in-law \\
\hline & Background & Hawali & Royalty \\
\hline & & Painting & House decoration \\
\hline & & Dusk & Night/evening tea time \\
\hline & & Urdu Text & Information \\
\hline & Colors & Metallic & Royal colors \\
\hline & & Cardamom & $\begin{array}{l}\text { Elaichi flavor/ taste in } \\
\text { culture }\end{array}$ \\
\hline
\end{tabular}


It's the story of a recessive male (Fahad Mustafa) that how he gets scared by his mother (Saba Hameed) and wife (sohai) in the whole ad. The TVC shows a stereotypical role of daughter in law and mother in law with the jealousy factor with each other. The story of the ad revolves around two dominated ladies and one receding male. In this commercial both women that are being shown in a big house signify high class, wearing heavy traditional jewelry signify status and money with their traditional dresses in eastern colors. The females in their characters show female dominancy over the only male who represents a poor man under the influence of both ladies. Moreover the overall women representation of female is in stereotype role with full of cultural material and traditional moods. Hence according to this TVC it is proved that $\mathrm{H}^{1}$ has been acknowledged after the semiotic analysis of the selected commercial.

\section{TVC 10: Shezan Satrang Achaar}

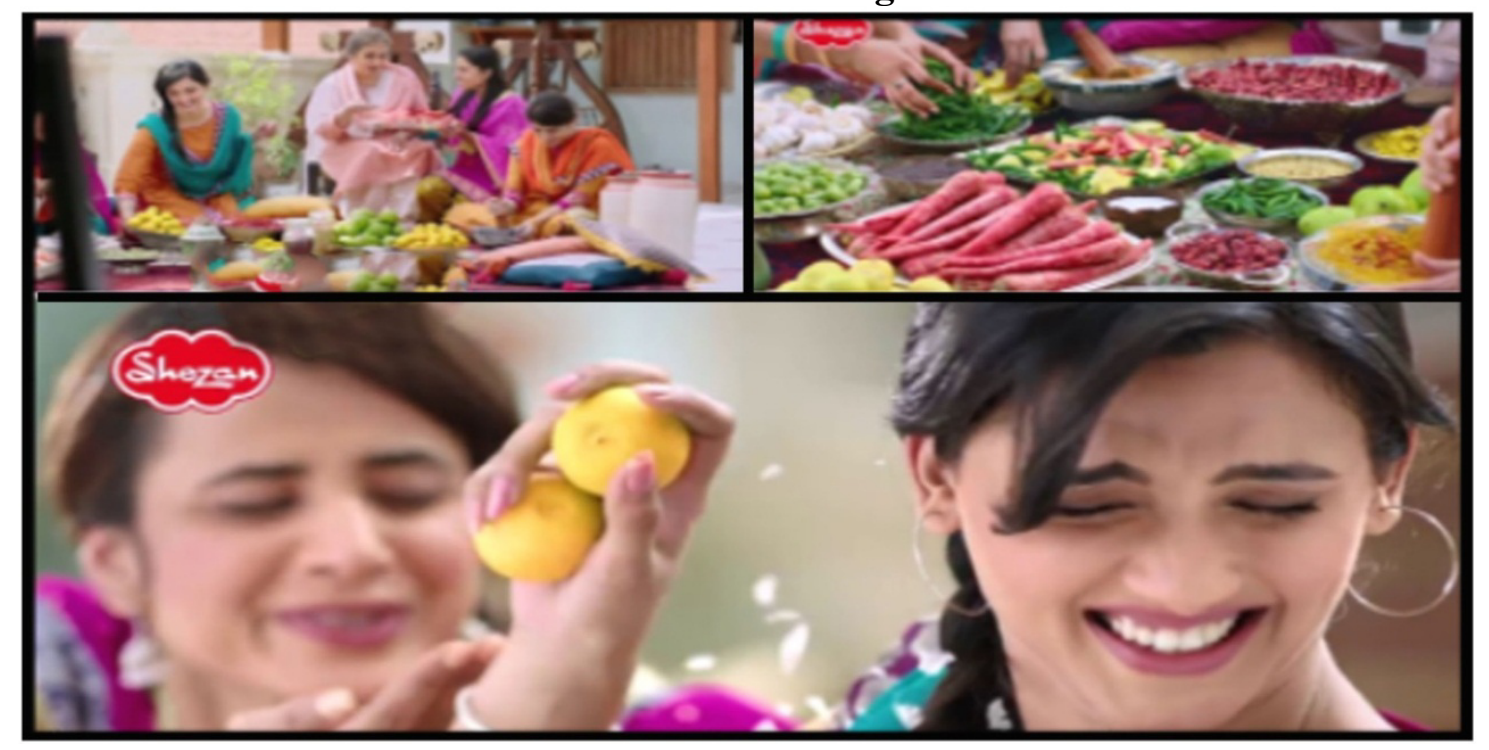

\begin{tabular}{|l|l|l|l|}
\hline $\begin{array}{l}\text { Shezan Satrung } \\
\text { Achaar }\end{array}$ & & Signifier & Signified \\
\hline & $\begin{array}{l}\text { Screen } \\
\text { Elements }\end{array}$ & & \\
\hline & & People sitting together & Culture/values \\
\hline & & Vegetables & Pickle preparation \\
\hline & Curry & $\begin{array}{l}\text { Mango pickle/mouth } \\
\text { watering }\end{array}$ \\
\hline & & Lemons in girl hand & Sour/vinegary \\
\hline & A group of girls & $\begin{array}{l}\text { Working together/mutual } \\
\text { work }\end{array}$ \\
\hline & & Grand mother & Old food recipe \\
\hline
\end{tabular}


104 Construction of Female Identity in Pakistani Television Commercials (November, 2015-April, 2016): A Semiotic Analysis

\begin{tabular}{|l|l|l|l|}
\hline & Spices & Ingredients \\
\hline & Shezan & Brand \\
\hline & Satrang pickle & Product \\
\hline & Packets and bottles & Different packaging \\
\hline & Girls giggling & blissful / happy \\
\hline & Carrots & Pickle ingredient \\
\hline & $\begin{array}{l}\text { Grandmother adding } \\
\text { spices }\end{array}$ & Preparing pickle \\
\hline & Bowl in girl hand & $\begin{array}{l}\text { Spice in bowl/ helping the } \\
\text { grand mother }\end{array}$ \\
\hline & & $\begin{array}{l}\text { Girls are wearing } \\
\text { shalwar qameez }\end{array}$ & Traditional / cultural \\
\hline & Earrings baliyan,bunday & $\begin{array}{l}\text { Typical jewellery/ } \\
\text { traditional }\end{array}$ \\
\hline & & Typical mixture /blender & Old utensil \\
\hline & & Girl in braid & Traditional hairstyle \\
\hline & & Chat patay rishton jaisa & Slogan/tagline \\
\hline & & Satrung ma satrangiya ha & $\begin{array}{l}\text { Advertisement catchy } \\
\text { sound track }\end{array}$ \\
\hline & Background & Traditional living style \\
\hline & & House roof & More emphasis on character \\
\hline & & Defocus & Brightness, love, happiness \\
\hline & & Multi-colors & \\
\hline & & &
\end{tabular}

The ad begins from an old constructed house where girls are preparing pickle ("achar") with the help of their grandmother that signifies the family culture and traditions. Like in past grandmothers used to make such stuff especially in summer for their family. Preparation of pickle signifies the summer and traditions. This commercial has shown an old tradition where few females sitting together and doing their work. Girls and mothers sitting together signify the old tradition and culture. Lemon in girl's hand signifies the real bunch sourness in this commercial. Grandmother and mother in this ad are shown as sign love and happiness of old traditions and old times when elder women used to be the central part of the family. A group of girls shows they are working together/ mutual work. Girls giggling and playing with excitement shows their blissful / happy life. Bowl in girl hand signify spice in bowl and she is helping the grandmother as it is necessary in old days to take part in house work and girls felt proud to help their elders.

In this ad girls are wearing bright colors of Pakistani national dress which signifies traditional and women identity. Traditional Earrings signifies cultural /traditional jewelry. 
Typical old utensils like in old days grandmothers used "chato batta" to blend the spices also reflects culture. Girls in braid (hairdo) signified the traditional look." Chat patay rishton jaisa" copy of the TVC merges with slogan "Satrung ma satrangiya ha", which signifies classic Urdu as a symbol of customs. House roof signify as traditional living style like the ancestors love to work on house roof specially for preparing pickle.

The women in this commercial constructed as traditional women of a middle class. By depicting the woman as being pleased of her ability in her home, the advertisements not only affirmed the traditional role of women but also made the domestic role of the woman appear natural to the viewers. It is evidenced that $\mathrm{H}^{1}$ has been acknowledged after the semiotic analysis of the selected commercial.

\section{Conclusions}

This research explored how television commercials in Pakistan construct woman identity, with reference to the acceptable concept of femininity in the minds of people. The first hypothesis of the research is that "Pakistani females are depicted in traditional role" and the second hypothesis of the research is that Pakistani TV advertisements "depict feminine as glamorous women" it is evidenced that in the present era most TVCs acknowledge $\mathrm{H}^{2}$ after applying the semiotic analysis methodology.

The signs present in television commercials do not just represent reality but are engaged in its production, although the work of ideology in signifying practices is always covered. Those who have power over the sign systems also manage the production of reality and construct it as they want. Semiotics can signify ideology at work and show that 'reality' can be tested (Chandler, 2001).

Semiotics can help to make us aware of the representation of gender roles in the world that what we take as simple or for granted, letting us know that we are continually watching the signs that are represented and not based on an objective reality. As sign frameworks are included in the construction of meaning (Chandler, 2001). Voloshinov (1973) stated that at every time when a sign is presented the ideology is also presented.

This research is concluded on the argument that Pakistani TV commercials amalgamated the amount of glamour and sex with the conception of traditional women. Most of the current commercials pay abundant importance in depicting women as glamorous and sexual icon and mislaid the actual insinuation of Pakistani women identity.

Commercials like Dalda cooking oil, Satrang achar, Nan khatai and Tarang elaichi depicts women as traditional while the commercials like Galaxy J1 Ace, Sunsilk Black 
shine, Lux peach soap, Freshup Elaichi, Hilal Cake Rusk, Q Mobile Noir S2 entirely tinted women as glamour sex symbol.

The first research question is that "how the female identity is being constructed by the advertising practitioners?" as the semiotics/ visual representations of the commercials proves that majority of the Pakistani TV commercial constructs women identity as glamorous women and rest of them constructs women identity as traditional women. It is concluded that the signs in the commercials reflect the reality but also represent the reality and constructed a new identity. These signs are the under control of dominant and powerful people who construct the reality.

The second research question "Are the women depicted in Pakistani Television commercials as glamorous and modern women?" In these commercials (Galaxy J1 Ace, Sunsilk Black shine, Lux peach soap, Freshup Elaichi, Hilal Cake Rusk, Q Mobile Noir S2) glamorous life is portrayed in late night parties where females attract men with their physical appeal where as traditional Pakistani society and religion limit women within a specific boundary don't permit them to practice such freedom at any cost.

As the third question is about the images of women in commercials that are these close to our traditions? In Pakistani system, no females are experienced as acting with males in physical conduct as appeared in the ad rather females carrying on in such way is viewed as obscene and her nearness is censured. Like in Lux and cake rusk ads are a major cases females are seen this type of scenes.

By analyzing these commercials it is concluded that the advertising practitioners use various devices such as costumes, colors, signs, symbols and metaphors to attract the audience. In addition, the visuals used as the sample of this study were ideologically contested. Based on the semiotic analysis, it can be summarized that out of ten TVCs only three ads represent women in traditional role which supports $\mathrm{H}^{1}$ while the rest of seven TV ads supports $\mathrm{H}^{2}$. Therefore it is concluded that the most obvious theme in Pakistani TVCs from November 2015 to April 2016, is that they depict Pakistani women as a liberal and glamorous women. Additionally it is perceived to become an affirmed part of the the female identity in the society (Roy, 1998).

\section{References}

Andrew. Edgar \& Sedgwick, Peter. (2008). Cultural Theory. The Key Concepts. Oxfordshire: Routledge.

Bezuidenhout, I. (1998). A Discursive-Semiotic Approach to Translating Cultural Aspects in Persuasive Advertisements, retrieved on May 13, 2016 from: http://ilze.org/semio/001.htm 
Barbera, C.1. \& Meade,M.(2010). Women Wellness, and the Media. International Journal Of Feminist Approaches To Bioethics, vol.3, pp.158-164, retreived on January 29, 2016 from: http://muse.jhu.edu/journals/international_journal_of_feminist_approaches_ to_bioethic s/summary/v003/3.1.la-barbera.html

Blakley, J. (2012). Media in Our Image. Women's Studies Quarterly, vol.40, pp.341-350, retrieved on March 17, 2016 from: http://muse.jhu.edu/journals/wsq/summary/ v040/40.12.blakely.html

Chandler, D. (2001). Semiotics for Beginners, retrieved on May 29, 2016 from: http://www.aber.ac.uk/media/Documents/S4B/sem10.html

Currie, D. (2004). The Girl on the Magazine Cover: The Origins of Visual Stereotypes in American Mass Media. Journal of Interdisciplinary History, vol.34, pp.480-482, retrieved on June 18, 2016 from: http://muse.jhu.edu/journal_of_interdisciplinary_ history/summary/v034/3 4.3currie.html

Correa, Deodrin Maria. (2011). The Construction of Gender Identity in India through Television Advertisements: A Semiotic Analysis, retrieved on June 12, 2016 from: http://dlibrary.acu.edu.au

Cole, \& Daniel, H. (2007). Media Analysis Book Offers Insightful Perspective on the Portrayal of Women-Featuring Females: Feminist Analyses of Media. Sex Role: A Journal of Research, vol.42, p.240, retrieved on May 28, 2016 from: http://link.springer.com/article/10.1007/s11199-007-9295-0/fulltext.html

Cuklanz, L.M. \& Mrooti, S. (2007). Television's "New" Feminism: Prime-Time Representations of women and victimization. Critical Studies in Media Communication, vol.24, pp.302-321, [Abstract] Media Abstract, 2007 Abstract No.10.1080 retrieved on June 17, 2016 from: http://www.tandfoline.com/doi/abs/ 07393180600933121

Das, M. (2011). Gender Role Portrayals in Indian Television Ads. Sex Roles: A Journal of Research, vol.64, pp.208-222. [Abstract] Social Abstract,2011,4,Abstract No.1119 retrieved on May 9, 2016 from: http://ink.springer.com/article/10.1007/ s11199-010-9750-1 
108 Construction of Female Identity in Pakistani Television Commercials (November, 2015-April, 2016): A Semiotic Analysis

Gill, R. (2008). Empowerment/Sexism: Figuring Female Sexual Agency in Contemporary Advertising. Feminism Psychology, vol.18, pp.35-60 [Abstract] Psychology Abstract. 2008 Abstract No.09593 retrieved on June 15, 2016 from: http://fap.sagepub.com/content/18/35.abstract

Halliwell, E., Malson, H., Tishchner, I. (2011). Are Contemporaray Media Images Whish Seem to Display Women as Sexually Empowered Actually Harmful to women. Psychology of Women Quarterly, vol.35, pp.38-45 [Abstract] Psychology Abstract.2011 Abstract No. 1177 retrieved on May12, 2016 from: http://pwq.sagepub.com/content/35/1/38.abstract

Kuperberg, A. \& Stone, P. (2008). The Media Depiction of Women Who Opt Out. Gender \& Society, vol.22, pp.497-517. [Abstract] Social Abstracts, 2008, 2, Abstract No10.1177, retrieved on April 5, 2016 from: http://gas.sagepub.com/content/22/4/497.short

Lanis, k. \& Covell, K. (2005). Images of Women in Advertisements: Effects on Attitudes Related to Sexual Aggression. Sex Roles: A Journal of Research, vol.32, pp.639649, [Abstract] Social Abstract, 2005, 9, Abstract No. 154426, retrieved on June 29, 2016 from: http://link.springer.com/article/10.1007/BF01544216

Lin, C, L. \& Yeh, J.T. (2009). Comparing Society's Awareness of Women: MediaPortrayed Idealized Images and Physical Attractiveness. Journal of Business Ethnic, vol.83, pp.101-112, [Abstract] Business abstract, 2009, 4, Abstract No.10551 retrieved on June 30, 2016 from: http://link.springer.com/article/ $10.1007 / \mathrm{s} 10551-009-0026-\mathrm{z}$

Lyer, R. (2009). Entrepreneurial Identities and the Problematic of Subjectivity in MediaMediated Discourses, Discourse Society, vol.20, pp.241-263 [Abstract] Social Abstract. 2009 abstract No. 92650 retrieved on June 30, 2016 from: http://das.sagepub.com/content/20/2/241.abstract

Lauzen, M.M. \& Dozier, D.M. (2005). Maintaing the Double Standard: Portrayals of Age and Gender in Popular Films. Sex Roles: A Journal of Research, vol.52, pp.437446, [Abstract] Social Abstract, 2005, 7, retrieved on June 29, 2016 from: http://link.springer.com/article/10.1007/s 11199-005-3710-1

Mohammadi, A. (2011). Critical Analysis of Women's Representation in TV Advertisements from a Cultural Studies Perspective, International Journal of Women's Research, vol.1, pp.107-122, retrieved on September 28, 2016 from: https://ijwr.ut.ac.ir/article_21844_0.html 
Purnima. (2011). Women's Issues in India: Role and Importance of Media. Global Media Journal, vol.4. [Abstract] Media Abstracts, 2011 Abstract No. 2070 Retrieved on May 9, 2016 from: http://www.aiou.edu.pk/gmj/Womens_issues_in_india_.asp

Plakoyiannaki, E. (2008). Images of Women in Online Advertisements of Global Products: Does Sexism Exist? Journal of Business Ethics, vol.83, pp.101-112, [Abstract] Business abstract, 2008, 1, Abstract No.9651 retrieved on April 5, 2016 from: http://link.springer.com/article/10.1007/s10551-007-9651-6

Priya, B. (2009). Faces of Indian Women in the Media: The Flawed Façade of "India shinning". ProQuest Dissertation \& Theses. 62, 1464057 [Abstract] Media abstract. 2009 Abstract No. 3452 03616, retrieved on June 15, 2016 from: http://gradworks.umi.com/14/64/1464057.html

Parsad, K. (2011). Young Women and the Modernity Project; Realities and Problems of Media Regulation in India, Journal of International Communication, vol.15, pp.925, [Abstract] international communication Abstract. 2011 Abstract No. 9674741 retrieved on July 7, 2016 from: http://www.tandfonline.com/doi/abs/10.1080

Poirot, k. (2003). Framed: Lesbians Feminists, and Media Culture. NWSA Journal, vol.15, 227-228, retrieved on July 15, 2016 from: http://muse.jhu.edu/journals/nwsa_ journal/summary/v015/15.2poirot.html

Radeloff, C.L. \& Bergman, B.J. (2009). Critical Thinking. Feminist Teacher, 19, 168-171 retrieved on July 15, 2016 from: http://muse.jhu.edu/journals/feminist_teacher/ summary/v019/19.2.radeloff.html

Ramasubramanian,S.,\& Oliver,M,B.(2003). Portrayal of Sexual Violence in Popular Hindi Films, 1997-99. Sex Roles. A Journal of Research, vol.48, pp.327336. [Abstract] Social Abstract, 2003,8 Abstract No. 1023, retrieved on June 17,2016 from: http://link.springer.com/article/10.1023/A\%3A1022938513819

Rendon, M.J. \& Nicolas, G. (2012). Deconstructing the Portrayals of Haitian Women in the Media; A Thematic Analysis of Images in the Associated Press Photo Archive. Psychology of Women Quarterly, vol.36, pp.227-239 [Abstract] Psychology Abstract.2012 Abstract No.03616, retrieved on July 17, 2016 from: http://pwq.sagepub.com/content/36/3/337.abstract

Steblea, J.J. (2010). Boys vs. Girls: How our Culture Creates a Conflict where both Sexes Lose. Women's Studies Quarterly, vol.38, pp.317-322, retrieved on June 23, 2016 from: http://muse.jhu.edu/journals/wsq/summary/vo38/38.3-4.steblea.html 
110 Construction of Female Identity in Pakistani Television Commercials (November, 2015-April, 2016): A Semiotic Analysis

Skalli (2006). Communicating Gender in the Public Sphere: Women and Information Technologies, Journal of Middle East Women's Studies, vol.2, pp.35-59 [Abstract] Women abstract.2006 Abstract No. 0023, retrieved on June 15, 2016 from: http://muse.jhu.edu/journals_of_middle_east_womens_studies/summary/v002/2.2 skalli.html

Verntte, E. (2004). Targeting Women's Clothing Fashion Opinion Leaders in Media Planning: An Application for Magazines. Journal of Advertising Research, vol.44, pp.90-107. [Abstract] Media Abstracts, 2004,01, retrieved on June 17,2016 from: http://journals.cambridge.org/action/display, Abstract from page $=$ online\&aid= 216376

Wimmer, R. D. \& Dominik, J. R. (2003). Mass Media Research An Introduction (9th ed.). Wadsworth Cengage Learning.

Moneeba Iftikhar is Lecturer in the Department of Mass Communication, Lahore College for Women University.

Mehwish Islam is B.S Student in the Department of Mass Communication, Lahore College for Women University. 